\title{
An integrated chemical and technological approach for assessing portuguese wheat flours quality and lengthening bread shelf-life
}

\author{
Fernando Cebola Lidon ${ }^{1,2, *}$, Diana Daccak, Paula Scotti-Campos ${ }^{2,3}$, Maria Manuela Silva ${ }^{2,4}$, \\ Ana Sofia Bagulho ${ }^{2,5}$, Isabel Pais ${ }^{2,3}$, Carlos Galhano, ${ }^{1,2}$, José Cochicho Ramalho, ${ }^{2,5}$, José Moreira ${ }^{5}$, \\ Maria Fernanda Pessoa ${ }^{1,2}$, Fernando Henrique Reboredo ${ }^{1,2}$ \\ ${ }^{1}$ Earth Sciences Department, Faculdade de Ciências e Tecnologia, Universidade Nova de Lisboa. Campus da Caparica, 2829-516 Caparica, \\ Portugal, ${ }^{2}$ GeoBioTec Research Unit, Faculdade de Ciências e Tecnologia, Universidade Nova de Lisboa. Campus da Caparica, $2829-516$ \\ Caparica, Portugal, ${ }^{3}$ INIAV - Instituto Nacional de Investigação Agrária e Veterinária, Oeiras, 2780-157, Portugal, ${ }^{4}$ PlantStress\&Biodiversity \\ Lab, LEAF Research Unit- Instituto Superior de Agronomia, Universidade de Lisboa, Quinta do Marquês, Av. da República, 2784-505 Oeiras, \\ Portugal, Escola Superior de Educação Almeida Garrett, Universidade Lusófona, Avenida do Campo Grande, $n^{\circ}$ 376, 1749-024, Lisboa, \\ Portugal, ${ }^{5}$ INIAV - Instituto Nacional de Investigação Agrária e Veterinária, Polo de Elvas, MADRP, Portugal
}

\section{A B S T R A C T}

The current trend of large-scale bread production is to facilitate processing at an industrial level, considering the use of flour mixtures with different chemical and technological parameters and incorporating food additives. Accordingly, costs can be minimized, whereas the quality and the shelf-life of the final product might increase, but a full characterization of the flours that must be used and the selection of the food additives to be incorporated into the dough is required. In this context, three Portuguese wheat flour varieties were evaluated (FariRamos, Nacional and AJMiranda), as well as two types of food additives with the aim to increase bread shelf-life. In these flours, the levels of K, S, P, $\mathrm{Ca}$ and $\mathrm{Cl}$ prevailed, but the moisture and ash contents of FariRamos were the highest and lowest, respectively. The colour of all flours was generally within the desired standard values. Nacional flour contained a higher fat content, but all the flours showed a higher relative abundance of linoleic acid (C18:2), followed by palmitic acid (C16:0) and oleic acid (C18:1). AJMiranda flour revealed a higher content of wet gluten and protein, but the SDS sedimentation index showed a higher value in the FariRamos flour. The fall index, which directly monitors the activity of the $\alpha$-amylase enzyme, showed a lower value in AJMiranda and Nacional. Through farinograph and alveographyc analysis it was found that FariRamos has a tenacious gluten, but AJMiranda and Nacional had a balanced gluten, yet all of them can be classified as medium flours. Bread making with a mix of FariRamos, AJMiranda and Nacional flours and incorporating preservative food additives revealed the highest shelf-life (11-days) with methyl p-hydroxybenzoate [0.05\%] and benzoic acid [0.1\%], but the colour of the breads showed a relationship of intensity of white colour that depended on the additive used. At the end of the shelf-life, molds of the Eurotium, Trichoderma and Cladosporium genera developed in the bread. It was concluded that the chemical and technological approach applied in the characterization of the flour varieties, can be directly used to define the quality and shelf-life in the bakery industry, allowing the establishment of minimum commercialization prices.

Keywords: Food additives; Shelf-life; Wheat bread; Wheat flours characterization

\section{INTRODUCTION}

Wheat comprises three species: Triticum monococcum, durum and aestivum, being classified according to their number of chromosomes (14, 28 and 42, respectively). The most commercially relevant species are Triticum durum (tetraploid - AABB) and Triticum aestivum (hexaploid - AABBDD), the latter corresponding to the usually designated common wheat (Edwards et al., 2001; Scheuer et al., 2011). Nevertheless, in each production field, species can reveal differentiating characteristics, depending on the wheat variety, since it has, besides genotypic differentiation, metabolic adaptations (i.e., adaptation, tolerance or resistance) to the edaphoclimatic factors of the ecosystem where it is grown. It is estimated that around 30,000 varieties of wheat belonging to 14 species are cultivated worldwide (Posner et al., 2005; Din et al., 2007).

Durum wheat (Triticum durum) is used worldwide to obtain mainly semolina which, by mixing and extruding with water,

\footnotetext{
${ }^{*}$ Corresponding author:

Fernando Cebola LidonK, Earth Sciences Department, Faculdade de Ciências e Tecnologia, Universidade Nova de Lisboa. Campus da Caparica, 2829-516 Caparica, Portugal. E-mail: fjl@fct.unl.pt
} 
can produce pasta (Elias, 1995). In addition it is also used in other products such as bulgur, couscous and frekeh. In the Mediterranean countries it is additionally used to produce bread, but a product with a low volume is obtained, as this baking processing lacks the elasticity of the gluten protein (Dick and Matsuo, 1988). Nevertheless, it can be indicated for production of bread and fermented products, due to its high protein content (Scheuer et al., 2011), but for baking at an industrial level, a better balance between extension resistance and extensibility is required (Edwards et al., 2001).

Triticum aestivum is called bread wheat since its elasticity allows a better bread quality, being thought to be due to the presence of genome D, which is absent in durum wheat (Edwards et al., 2001). It is mainly used in baking, but also for the production of cookies (crackers), cakes and pies, because it has a low protein absorbing constituent's content, which allows good extensibility (Scheuer et al., 2011). Wheat grain also has a great protein heterogeneity, but albumin, globulin, gliadin and glutenin prevail. Although they constitute only nutrient reserves (mostly N, C, S) for seed development, gliadin and glutenin represent about $80 \%$ of total proteins, and both protein groups are referred to as prolamines (Bagulho, 2008). Besides, they are responsible for gluten network formation, which is responsible for retaining the carbon dioxide produced during the fermentation and the mechanical behaviour of dough (Lucas et al., 2019) The viscoelastic properties of the masses are determined by the protein content. Glutenins are mainly responsible for the elasticity and strength of the dough, while gliadins gives viscosity. It should also be noted that high-quality bread-producing grain cultivars have large proportions of high molecular weight glutenin polymers (Din et al., 2007).

In wheat carbohydrates starch predominate, namely in the form of granules within amyloplasts in the endosperm. These granules are divided into three types (A, B, C), according to size and shape. The chemical and physical properties of starch, as well as its functionality, are influenced by the proportions and types of granules that constitutes it. Two starch types of polysaccharides, amylopectin $(75 \%)$ and amylose $(25 \%)$ occurs. These two constituents have a different structure, being amylopectin a branched polymer and amylose a linear molecule (Bagulho, 2008). The functional and nutritional characteristics of starch are mainly due to the physical state of the food, which changes during processing through two stages (Scheuer et al., 2011): gelatinization, which results from heating the starch in the presence of sufficient moisture, puffing up the granules (due to water absorption and thus losing crystallinity); retrogradation, which determines a new crystallization of gelatinized starch chains.
Lipids also occur in a very small percentage in wheat grain (ca. 3-4\%), and are not evenly distributed in the grain, subsisting mainly in the germ (Araujo 1990; Ortolan, 2006). In cereal grains they can be found essentially in the form of triacylglycerols or stock lipids, being fatty acids an important fraction (Becker, 2007). Some of the fatty acids in wheat grain are essential for health, namely palmitic (C16:0), oleic (C18:1) and linoleic (C18:2) acids. In more complex foods lipids are still involved in the development of aroma and taste characteristics and also influence texture (Sgarbieri, 1987; El-Dash et al., 1990). Besides, the levels of minerals and vitamins are also very low in wheat grain (about 1.5 to $2.5 \%$, with phosphorus having a higher concentration $16-22 \%$ of the total ash content).

Among the ingredients used in bread production, flour and water play a very important role, affecting the texture and crumb of the final product. The process comprises three fundamental steps (Scheuer et al., 2011): mixing/ kneading, occurring at this stage the development of gluten viscoelastic properties, in addition to the incorporation of air, which has greater effect on rheology and texture; fermentation, a step that involves the action of natural enzymes; cooking, a process in which some changes occur in the product that define sensory aspects, such as moisture vaporization, temperature rise, volume increase, transformation of dough viscosity into bread crumb elasticity and spongy dough characterization.

Bread has a shelf-life which may vary with the development of mold. However, their growth depends on $\mathrm{pH}$, moisture, redox potential, nutrients and the presence of inhibitors (biochemical or physical) in the bread (Freitas and Figueiredo, 2000). In this context, it should be noted that, at the macroscopic level, a first identification of the fungus genus is possible through certain characteristics such as colony diameter, presence or absence of edge, zonation, roughness, elevation and exudate, and the texture and its colour. For instance, the genus Eurotium, forms yellow colonies, whereas Trichoderma, with rapid growth and white colonies, forms green or yellow tufts after one week of growth and Cladosporium shows black colonies (Freitas and Figueiredo, 2000; Almeida et al., 2010).

To preserve bread, preservative food additives can be used. However, the use of preservative food additive can be affected by the presence of other microorganism growth inhibitors, such as salt, vinegar and sugar, product $\mathrm{pH}$ and composition, food water content and the initial level of contamination, either food or environmental (Lidon and Silvestre, 2010; Silva and Lidon, 2016). Organic acids and their derivatives are frequently used in beverage, food, and feed production. Acidic additives may act as buffers 
to regulate acidity, antioxidants, preservatives, flavor enhancers, and sequestrants (Quitmann et. al., 2014).

Among the organic acids with a higher antimicrobial activity stands out the benzoic acid. Acetic acid is less efficient and is generally applied at much higher concentrations (Lidon and Silvestre, 2007, 2008, 2010; Silva and Lidon, 2016). Only acetobacter, lactic acid bacteria and butyric bacteria are tolerant to acetic acid. As for fungi, they are more resistant, but there are some sensitive ones like Aspergillus, Penicillium, Rbizopus and Sacharomyces (Lidon and Silvestre, 2007, 2008, 2010; Silva and Lidon, 2016). The recommended dosage is 0.1 - 5 \% (Lidon and Silvestre, 2007, 2008, 2010; Silva and Lidon, 2016). Due to its different solubilities, undissociated benzoic acid, although more effective, is poorly soluble in water, being preferably the use of sodium benzoate, which is more soluble in water (Lidon and Silvestre, 2010; Silva and Lidon, 2016). The $\mathrm{pH}$ range that provides the best efficiency is 2.5 to 4.0 , and the lower the food $\mathrm{pH}$, the lower the benzoic acid concentration required for the preservative action (Lidon and Silvestre, 2007, 2008, 2010; Silva and Lidon, 2016). Its use in fermented foods is restricted as it is active against lactobacilli. In addition, it gives a strong and spicy taste and is also restricted to certain products for this reason. The usual dosage ranges vary between $0.05-0.1 \%$ (Lidon and Silvestre, 2007, 2008, 2010; Silva and Lidon, 2016). The use of p-hydroxybenzoic acid in food gives it an unpleasant taste and is little used. Parabens are alkyl esters of p-parahydrobenzoic acid. The major ones are methyl p-hydroxybenzoate, ethyl p-hydroxybenzoate, propyl p-hydroxybenzoate and butyl hydroxybenzoate. Its water solubility depends on the nature of the alkyl group and the longer the paraben chain length, the lower the solubility (Lidon and Silvestre, 207, 2008, 2010; Silva and Lidon, 2016). They are efficient in a $\mathrm{pH}$ range between 3 and 8, being more active at low pH (Lidon and Silvestre, 2010; Silva and Lidon, 2016).

The aim of the present study is to develop a structured and integrated chemical and technological approach, for evaluating bread wheat flours using, as test system, the Portuguese flour varieties FariRamos, Nacional and AJMiranda, and further considering the addition of food additives - methyl p-hydroxybenzoate [0.05\%] and benzoic acid [0.1\%], their mode of action and effects on dough rheology, in order to increase bread shelf-life.

\section{MATERIALS AND METHODS}

Three Portuguese types of flour (FariRamos, AJMiranda e Nacional) were furnished by the INIAV - Portuguese Veterinarian and Agrarian Research Institute (Elvas, Portugal), consisting the blend developed for bread making of equal parts of each flour.
Using an X - ray analyser (Niton Thermal Scientific, model $\mathrm{Xlt}$ ), the minerals of the flour were determined. The obtained values resulted from the energetic detection of electrons according to the electromagnetic spectrum in the range of $\mathrm{X}$ - rays emitted by the elements that make up the sample (Groover and Izbicki, 2016). Three samples were processed for each wheat variety, with each reading lasting 360 seconds.

The moisture content of wheat flour was determined according to NP - 516/2000 (2000), on the water content for cereals and derivatives. Three samples of each flour with $5 \mathrm{~g}$ were weighed and placed in the oven at $130{ }^{\circ} \mathrm{C}$ for 90 minutes. After, the weight was determined and the moisture was calculated according to the following formula:

$$
H(\%)=\left(1-\frac{\text { pasta after dryness }}{\text { pasta before dryness }}\right) \times 100
$$

Following NP 519/1993 (1993), the percentage of ashes was measured. Five grams of sample was used and, after incineration at $900{ }^{\circ} \mathrm{C}$ for 2 hours, and cooling to room temperature, the ash content was determined according to the formula:

$$
\text { Ashes }(\%)=\left(\frac{\text { Ashes weight }}{\text { wet sample weight }}\right) \times 100
$$

Colorimetric analysis of flour and bread samples was performed with a colorimeter (CR-400 Konica Minolta). Nine readings from 9 different samples of flour were performed. Regarding bread, each was cut in half and the two halves were analysed in duplicate (crumb and outer top and bottom of the bread). Data were expressed according to the CIELab system (Commission Internationale de Éclairage, colour space L, a *, b*) where $\mathrm{L}$ represents the brightness ranging from 0 (black) to 100 (white), $a^{*}$ (green when negative and red when positive) and $b^{*}$ (yellow when positive and blue when negative) (Fukunaga, 1970).

Extraction of total lipids was performed according to Bligh and Dyer (1959) adapted by Bahhrami et al. (2014). In order to identify the fatty acid chromatographic peaks, the retention times of each fatty acid methyl ester were compared to standards (Oliveira, 2012).

Protein content followed the Kjeldahl method (ISO 20483-E, 2006). The total amount of $\mathrm{N}$ was used to measure the crude protein, converting this value to crude protein, considering that the whole $\mathrm{N}$ is in protein form. Values were expressed as a percentage according to the following formula: 


$$
\mathrm{wN}=\frac{(\mathrm{V} 1-\mathrm{V} 0) \times \mathrm{T} \times 0,014 \times 100}{\mathrm{~m}} \times \frac{100}{100-\mathrm{wH}}
$$

where $\mathrm{V} 0$ is the sulfuric acid volume $(\mathrm{mL})$ of the blank test, $\mathrm{V} 1$ is the sulfuric acid volume $(\mathrm{mL})$ of the test portion, 0.014 is the value $(\mathrm{g})$ of the amount of $\mathrm{N}$ equivalent to the use of $1 \mathrm{~mL}$ of a sulfuric acid solution $\left(0.05 \mathrm{~mol} \mathrm{~L}^{-1}\right)$, T corresponds to the normality of the sulfuric acid solution used in the titration, $\mathrm{m}$ corresponds to the mass ( $\mathrm{g}$ ) of the test portion and $\mathrm{wH}$ corresponds to the moisture content.

The determination of the SDS sedimentation index consisted of measuring gluten strength by joining the sample proteins with a dodecyl lactic acid stock solution previously prepared with sodium sulfate (SDS) according to Dick and Quick (1983) and Mandarino (1993).

The determination of the fall rate, which allows the prediction of the behaviour of $\alpha$-amylase enzymes during fermentation (Dick and Quick, 1983), was performed according to ISO 3093:2009 (2009). This parameter is expressed in seconds (Monho, 2013).

Determination of the wet gluten content in the samples was performed according to the mechanical extraction method, using a Glutomatic equipment (Perten Instruments AB) and following ISO 21415-2:2006-E (2006). Results were calculated using the formula:

Gwet $=\mathrm{m} 1 \times 100 \%$ (being $\mathrm{m} 1$ the wet gluten mass expressed in $g$ )

From wet gluten, the dry gluten content was determined by the fast drying method and according to ISO 214154:2006.E (2006). A portion of the previously obtained wet gluten was removed and placed in an electrically heated drying plate. After drying, the dry gluten was weighed and the results were calculated according to the formula:

$$
\text { Gdry }=\frac{\mathrm{m} 6}{\mathrm{~m}} \times 100 \%
$$

(where $\mathrm{m} 6$ corresponds to the dry gluten mass expressed in $\mathrm{g}$, and $\mathrm{m}$ corresponds to the mass used to determine the wet gluten content, also expressed in g).

Following ISO 5530-1:2013-E (2013), and using a farinograph, the consistency of the dough as it forms from flour and water, as well as its development and changes over time was determined in three samples of each flour. The amount of water needed to obtain a fixed dough consistency was thus estimated (Almeida et al., 2010). The parameters obtained were: Absorption - volume of water required to produce a mass with a maximum consistency of $500 \mathrm{UF}$ (Farinophagous Units). It is expressed as a percentage; Development time - time from the start of water addition to the point immediately before the first decrease in maximum consistency; Stability - time interval during which the curve intersects the 500 UF line. Indicates tolerance to kneading; Degree of weakening - difference between the centre of the curve, at the point where the decrease begins, and the centre of the curve 12 minutes after that point; Quality number - length, expressed in $\mathrm{mm}$, from the point of addition of water to the point where the height of the curve decreases by $30 \mathrm{FU}$ (Bagulho, 2008).

According to ISO/DIS 27971:2014-E (2014), in three samples of each flour, the alveographic test was performed using a blender with a kneader and a relaxocalculator, that allowed the automatic measurement and recording of data, which summed up the behaviour of the mass during fermentation (Zardo, 2010). The flour was firstly hydrated with a sodium chloride solution, depending on its moisture content and the mixture kneaded. Some mass discs were extracted and tested after about 20 minutes. The balloon formation by "insufflation" was recorded until it ruptured. In relation to the curve resulting from the average of the disks, the following parameters were determined: Force (W) - energy, expressed in $10^{-4} \mathrm{~J}$, necessary to deform $1 \mathrm{~g}$ of mass until its rupture; Tenacity $(\mathrm{P})$ - the maximum pressure, expressed in $\mathrm{mm}$, required to deform the mass, corresponding to its resistance to deformation; Extensibility (L) - maximum extent that the mass can reach without breaking; Equilibrium ratio $(\mathrm{P} / \mathrm{L})$ - relationship between toughness and extensibility and corresponding to the curve configuration (Rocha, 2009).

The bread's shelf-life was determined in three bread samples per treatment, by cutting into two parts and spraying it with the following food additives: acetic (3\% and $4 \%$ ), benzoic $(0.05 \%$ and $0.1 \%)$ and methyl p-hydroxybenzoate $(0.03 \%$ and $0.05 \%$ ) acids (E260, 210 and E219, respectively). Therefore, the molds on the bread were observed at a macroscopic and microscopic levels (using a binocular magnifying glass Leica M165 C - Leica Microsystems and a scanning electron microscopy - Jeol 330).

The experimental results were evaluated by one-way analysis of variance (ANOVA) to determine significant differences between the analysed samples. Significance was also determined by the $\mathrm{F}$ test using the Tukey test $(\mathrm{p} \leq 0.05)$ for comparative study of means. IBM SPSS Statistics 20.0 software (IBM Corp. Released 2011. IBM SPSS Statistics for Windows, Version 20.0. Armonk, NY: IBM Corp.) was used to perform the statistical processing of the data. 


\section{RESULTS AND DISCUSSION}

Computer technology and high-resolution X-ray detectors have made energy-dispersive X-ray fluorescence spectrometry a practical, rapid and sensitive technique for quantitative analysis of mineral elements in biological materials (Peterson et al., 1983). This technique provides the advantage of simultaneous multinutrients analysis and, because it is a non-destructive technique, losses encountered in chemical methods during dry ashing and acid extractions are avoided. X-ray fluorescence spectrometry analysis showed that (Table 1) contents of $\mathrm{K}, \mathrm{S}$ and $\mathrm{P}$ in the three flour varieties ranged between $0.23-0.27 \%, 0.27-0.29$ $\%$ and $0.15-0.17 \%$, respectively. In AJMiranda the concentration of $\mathrm{K}$ and $\mathrm{P}$ were significantly lower, but $\mathrm{S}$ did not revealed significant differences relatively to the other flours (Table 1). The contents of $\mathrm{Cl}$ and $\mathrm{Ca}$ in all the flours ranged between 674 - $699 \mathrm{ppm}$ and 330 - $360 \mathrm{ppm}$, respectively (Table 1). However, $\mathrm{Cl}$ also showed no significant variations in the three types of flour, whereas Ca revealed a higher concentration in FariRamos flour. Peterson et al. (1983) studying 27 wheat flour varieties, and Rennan et al. (2008) analysing 55 wheat flour varieties, found substantial variations among the levels of $\mathrm{K}, \mathrm{S}, \mathrm{P}$, $\mathrm{Cl}$ and $\mathrm{Ca}$ which, were related with the diverse genetic makeup, agronomic characteristics and productivity of the cultivars. Accordingly, the variations found for $\mathrm{K}, \mathrm{P}, \mathrm{S}, \mathrm{Cl}$ and $\mathrm{Ca}$ (Table 1), which are somewhat higher than these found by other authors for a large amount of wheat flour varieties (Peterson et al., 1983; Rennan et al., 2008; Dias et al., 2009a, b), also might be linked to the heterogeneity of cultivars and to the applied bread wheat production technology. Nevertheless, FariRamos, AJMiranda and Nacional flour varieties (Table 1) showed a high nutritional

Table 1: Minerals content in wheat flours

\begin{tabular}{|c|c|c|c|c|c|c|c|c|}
\hline \multirow[t]{3}{*}{ Flours } & \multicolumn{8}{|c|}{ Minerals } \\
\hline & K & $S$ & $\mathbf{P}$ & $\mathrm{Cl}$ & $\mathrm{Ca}$ & Si & Sn & Mo \\
\hline & \multicolumn{3}{|c|}{$\%$} & \multicolumn{5}{|c|}{ ppm } \\
\hline FariRamos & $0.26^{a, b}$ & $0.29^{a}$ & $0.17^{a}$ & $699^{a}$ & $360^{a}$ & $543^{a}$ & $9.19^{a}$ & $4.3^{a}$ \\
\hline AJMiranda & $0.23^{b}$ & $0.28^{a}$ & $0.15^{b}$ & $692^{a}$ & $340^{b}$ & $606^{a}$ & $8.65^{a}$ & $4.4^{\mathrm{a}}$ \\
\hline Nacional & $0.27^{a}$ & $0.27^{a}$ & $0.17^{\mathrm{a}}$ & $674^{\mathrm{a}}$ & $330^{\mathrm{b}}$ & $542^{a}$ & $6.87^{\mathrm{a}}$ & $4.6^{a}$ \\
\hline
\end{tabular}

Each value is the mean \pm S.E. of three samples of each flour; Letters

$\mathrm{a}, \mathrm{b}$ indicate significant differences, of each parameter, among wheat

flours (statistical analysis using the one-way analysis of variance, $P \leq 0.05$ ) value for human consumption. The concentrations of $\mathrm{Si}, \mathrm{Sn}$ and Mo did not vary significantly between the three flours (Table 1), ranging from $542-606 \mathrm{ppm}, 6.87-9.19 \mathrm{ppm}$ and 4.3 - $4.6 \mathrm{ppm}$, respectively.

FariRamos flour, compared to the other flours, showed a significantly higher moisture content (13.1\%), but the ash concentration was significantly lower (Table 2). The moisture content of all flours remained within the range for wheat flours (Silva et al. 2010), which is an indication of a high commercial value. Yet, although the ash content is a relevant benchmark as it gives an indication of the total mineral content, it also influences colour, as white flour has a lower ash content relatively to the whole flour (Remelgado, 2016). Indeed, the whiter the flour, the higher the quality grade is considered (Silva, 2003). In this framework, using the colorimetric analysis and considering the CIELab system, white flour should have $\mathrm{L}$ values greater than 94 , coordinate $\mathrm{a}^{*}$ near zero (either negative or positive) and coordinate $\mathrm{b}^{*}$ around from +8 (Oliveira, 2012). Comparing the colorimetric parameters of the three types of flour, it was found that in relation to the parameters $\mathrm{L}, \mathrm{a}^{*}$ and $\mathrm{b}^{*}$ there were no significant differences (Table 2). All types of flour showed a high brightness and tending towards white, although with a slight hue to yellow, as relatively to the parameter L they were slightly below 94 , while compared to the parameter $\mathrm{a}^{*}$ they were close to 0 , and $\mathrm{b}^{*}$ presented values somewhat higher than 8 .

Total fatty acid contents were (Table 2), relative to AJMiranda and FariRamos flours, significantly higher in the Nacional flour $\left(20.0 \mathrm{mg} \mathrm{g}^{-1}\right.$ Dw $)$. In contrast, AJMiranda and FariRamos flours had similar total fatty acid contents (12.8 and $15.5 \mathrm{mg} \mathrm{g}^{-1}$ Dw, respectively). Nevertheless, although the contents of total fatty acids remained within the range usually measured in wheat flours (Silva et al., 2010), all flours showed a double bond index without significant differences (Table 3). Considering that the double bond index indicates the degree of unsaturation of total fatty acids, it was found that the highest total acids content of the Nacional flour $(6.3 \%)$ was not due to a higher degree of lipid unsaturation (i.e. a higher abundance of doublebonded fatty acids), which could favour rancidification.

Table 2: Analytical parameters of wheat flours

\begin{tabular}{|c|c|c|c|c|c|c|c|c|c|c|c|c|}
\hline \multirow[t]{2}{*}{ Flours } & \multirow{2}{*}{$\begin{array}{c}\text { Moisture } \\
\% \\
\end{array}$} & \multirow{2}{*}{$\begin{array}{c}\text { Ashes } \\
\% \\
\end{array}$} & \multicolumn{3}{|c|}{$\begin{array}{l}\text { Colorimetric } \\
\text { parameters }\end{array}$} & \multirow{2}{*}{$\begin{array}{c}\text { Total fatty } \\
\text { acids (TFA) } \\
\mathrm{mg} \mathrm{g}^{-1} \mathrm{DW}\end{array}$} & \multirow{2}{*}{$\begin{array}{c}\begin{array}{c}\text { Double bond } \\
\text { index of TFA }\end{array} \\
\% \\
\end{array}$} & \multirow{2}{*}{$\begin{array}{c}\begin{array}{c}\text { Wet } \\
\text { gluten }\end{array} \\
\% \\
\end{array}$} & \multirow{2}{*}{$\begin{array}{c}\begin{array}{c}\text { Dry } \\
\text { gluten }\end{array} \\
\%\end{array}$} & \multirow{2}{*}{$\begin{array}{c}\text { Proteins } \\
\% \\
\end{array}$} & \multirow{2}{*}{$\begin{array}{c}\text { Fall rate } \\
s\end{array}$} & \multirow{2}{*}{$\begin{array}{c}\begin{array}{c}\text { SDS } \\
\text { index }\end{array} \\
\mathrm{mm} \\
\end{array}$} \\
\hline & & & $L$ & $a^{*}$ & $b^{*}$ & & & & & & & \\
\hline FariRamos & $13.1^{a}$ & $0.47^{b}$ & $90.5^{a}$ & $0.12^{a}$ & $9.9^{\mathrm{a}}$ & $15.5^{b}$ & $5.5^{a}$ & $27.7 c$ & $9.2^{a}$ & $12.1^{b}$ & $354.0^{b}$ & $100.5^{a}$ \\
\hline AJMiranda & $12.8^{b}$ & $1.13^{\mathrm{a}}$ & $89.4^{a}$ & $0.11^{a}$ & $10.1^{\mathrm{a}}$ & $12.8^{b}$ & $5.7^{\mathrm{a}}$ & $31.1^{\mathrm{a}}$ & $9.9^{\mathrm{a}}$ & $12.5^{\mathrm{a}}$ & $414.5^{\mathrm{a}}$ & $97.0^{\mathrm{b}}$ \\
\hline Nacional & $12.7^{b}$ & $1.43^{\mathrm{a}}$ & $91.0^{\mathrm{a}}$ & $0.14^{a}$ & $10.0^{a}$ & $20.0^{a}$ & $6.3^{a}$ & $29.1^{\mathrm{b}}$ & $9.4^{\mathrm{a}}$ & $11.6 c$ & $417.0^{\mathrm{a}}$ & $95.5^{\mathrm{b}}$ \\
\hline
\end{tabular}

Each value is the mean \pm S.E. of three samples of each flour; Letters $a, b$ indicate significant differences, of the average value of each parameter, among wheat flours (statistical analysis using the one-way analysis of variance, $\mathrm{P} \leq 0.05)$. Double bond index $=[(\%$ monoenes $+2 \mathrm{x} \%$ dienes $+3 \mathrm{x} \%$ trienes $) /(\%$ saturated fatty acids)], according to Mazliak (1983) in 3 flour varieties 
In this context, the fatty acid profile of all flours (Table 3) showed a higher relative abundance of linoleic acid (C18: 2), followed by palmitic acid (C16:0) and oleic acid (C18:1), ranging from $11-69 \%$ (Silva, 2003). The remaining stearic acid (C18:0) and linolenic acid (C18:3) were between $2-4 \%$. The different fatty acids did not present significant variations among the three flours. However, FariRamos showed the highest value for palmitic acid $(22.2 \%)$ and Nacional the lowest (19.1\%). Stearic acid showed similar values for FariRamos and Nacional $(3.2 \%)$, as well as for AJMiranda $(2.9 \%)$. Oleic acid had a higher value in Nacional (12.2 \%), followed by FariRamos (11.8 \%), and finally by AJMiranda $(11.3 \%)$. Linoleic acid revealed the highest value in Nacional (59.9\%), with FariRamos $(56.9 \%)$ showing the lowest value. For linolenic acid the largest value belonged to FariRamos (4.1\%) and the lowest value to AJMiranda flour (3.2\%).

Wet gluten contents were significantly different among the three flours (Table 2). AJMiranda had a higher value (31.1\%), followed by Nacional (29.1\%) and FariRamos $(27.7 \%)$. In contrast, dry gluten contents showed no significant differences (Table 2), with AJMiranda flour having the highest value $(9.9 \%)$ and FariRamos the lowest $(9.2 \%)$. The higher moisture gluten content in AJMiranda showed a greater hydration capacity (Stanley, 2007). In baking, gluten content is particularly relevant as it is responsible for retaining the gas from fermentation in the dough, giving lightness to the fermented products, thus being related to the final quality of the products, providing a better texture, shape and expansion (Scheuer et al., 2011). Thus, the high-gluten of the Nacional flour forms stronger and more elastic masses, as opposed to the low-gluten flours, such as FariRamos. Like gluten,

Table 3: Fatty acids content of wheat flours

\begin{tabular}{lccc}
\hline Fatty acids (mol \%) & \multicolumn{3}{c}{ Flours } \\
\cline { 2 - 4 } & AJMiranda & Nacional & FariRamos \\
\hline C16:0 & $22.0 \pm 2.0^{\mathrm{a}}$ & $19.1 \pm 1.2^{\mathrm{a}}$ & $22.2 \pm 2.1^{\mathrm{a}}$ \\
C18:0 & $2.9 \pm 0.2^{\mathrm{a}}$ & $3.2 \pm 0.4^{\mathrm{a}}$ & $3.2 \pm 0.3^{\mathrm{a}}$ \\
C18:1 & $11.3 \pm 0.5^{\mathrm{a}}$ & $12.2 \pm 0.8^{\mathrm{a}}$ & $11.8 \pm 0.5^{\mathrm{a}}$ \\
C18:2 & $58.0 \pm 1.6^{\mathrm{a}}$ & $59.9 \pm 0.9^{\mathrm{a}}$ & $56.9 \pm 2.7^{\mathrm{a}}$ \\
C18:3 & $3.2 \pm 0.1^{\mathrm{a}}$ & $3.7 \pm 0.3^{\mathrm{a}}$ & $4.1 \pm 0.5^{\mathrm{a}}$ \\
$\sum<1 \%$ & $2.6 \pm 0.2^{\mathrm{a}}$ & $2.0 \pm 0.1^{\mathrm{ab}}$ & $1.7 \pm 0.2^{\mathrm{b}}$ \\
\hline
\end{tabular}

Each value is the mean \pm S.E. of three samples of each flour; Letters a,bindicate significant differences, of each parameter, among wheat flours (statistical analysis using the one-way analysis of variance, $\mathrm{P} \leq 0.05$ ) also the protein content, relates to the quality of the finished product (i.e., texture and appearance). Protein content was significantly different in all the flours, with AJMiranda having the highest value (12.5\%) and Nacional flour $(11.6 \%)$ showing the lowest content (Table 2). For soft products, namely cakes, a lower protein content is required, but for products with a harder texture such as bread, higher levels are preferable (Stanley, 2007). However, a product may have a high protein content but this protein is of low quality and, in contrast, a lower protein content may overlap a higher quality, thus also influencing the final product. In this context, assuming as a reference that in the manufacture of French bread the ideal protein content should oscillate between $10.5-13.0 \%$, it was found that AJMiranda, FariRamos and Nacional flours are in the range considered ideal for bread making (Guarienti, 1996).

The Nacional flour showed a higher value for the fall index (417.0 s), followed by AJMiranda (414.5 s) and FariRamos having the significantly lowest value (354.0 s) (Table 2). The fall index is directly related to the activity of the $\alpha$-amylase enzyme. Increased $\alpha$-amylase activity causes saccharification of starch molecules during the bread making process, resulting in breads with a sticky and moist internal texture. However, low activity results in a final product with a dry and brittle inner texture (Guarienti, 1996). According to (Guarienti, 1996), a high enzymatic activity is considered if values are below $200 \mathrm{~s}$; ideal values occur if ranged between 201-350 s; a low enzyme activity prevails if values are $\geq 351 \mathrm{~s}$. Thus, AJMiranda and Nacional flours showed low $\alpha$-amylase enzyme activity, with FariRamos being in the range of values considered ideal and also low in activity (therefore better than the others in this characteristic).

The SDS sedimentation index, which indicates gluten strength, showed for FariRamos (Table 2) significantly higher value $(100.5 \mathrm{~mm})$, in contrast to the Nacional that revealed the lowest value $(95.5 \mathrm{~mm})$.

All the flours showed significantly different values for the absorption index (Table 4). FariRamos presented the highest values $(61.0 \%)$, with the lowest value occurring in the Nacional flour $(58.1 \%)$. In contrast, development times, stability, weakness and quality number did not differ significantly among all the flours (Table 4). The development time presented higher values for AJMiranda

Table 4: Farinograph parameters linking to the consistency of the dough from flour and water

\begin{tabular}{|c|c|c|c|c|c|}
\hline Flours & Absorption (\%) & Development time (min) & Stability (min) & Weakness (UF) & Quality number \\
\hline FariRamos & $61.0 \pm 0.3^{a}$ & $1.9 \pm 0.2^{a}$ & $4.0 \pm 1.1^{a}$ & $49.0 \pm 21.2^{a}$ & $67.5 \pm 30.4^{a}$ \\
\hline AJMiranda & $59.6 \pm 0.1^{b}$ & $2.1 \pm 0.6^{a}$ & $6.5 \pm 1.7^{a}$ & $49.5 \pm 13.4^{a}$ & $72.0 \pm 7.1^{\mathrm{a}}$ \\
\hline Nacional & $58.1 \pm 0.2^{c}$ & $1.8 \pm 0.4^{a}$ & $4.4 \pm 1.3^{a}$ & $55.0 \pm 4.2^{a}$ & $55.0 \pm 22.6^{a}$ \\
\hline
\end{tabular}

Each value is the mean \pm S.E. of three samples of each flour; Letters ${ }^{a, b, c i n d i c a t e ~ s i g n i f i c a n t ~ d i f f e r e n c e s, ~ o f ~ e a c h ~ p a r a m e t e r, ~ a m o n g ~ w h e a t ~ f l o u r s ~(s t a t i s t i c a l ~}$ analysis using the one-way analysis of variance, $\mathrm{P} \leq 0.05$ ) 
(2.1 min), followed by FariRamos (1.9 min) and lastly for the Nacional flour (1.8 min). As for stability, a higher value was observed for AJMiranda (6.5 min) and the lowest for FariRamos (4.0 min). For the weakening, the Nacional flour showed the highest value (55.0 UF), with FariRamos displaying the lowest value (49.0 UF). Regarding the quality number, the highest value occurred in AJMiranda (72.0), followed by FariRamos (67.5), with the last being revealed in the Nacional flour (55.0). A weak flour has $<55 \%$ absorption, $<2.5$ min development time, $<3$ min stability and $>100$ UF weakening. A medium flour has an absorption of $54-60 \%$, development time $2.5-4.0 \mathrm{~min}$, stability 3-8 min and weakening 60-100 UF. A strong flour has an absorption $>58 \%$, development time $4.0-8.0$ min, stability 8 - 15 min and weakening 15-50 UF. A very strong flour has an absorption $>58 \%$, development time $>10.0 \mathrm{~min}$ stability $>15$ min and weakening $<10 \mathrm{UF}$ [51]. Thus all the flour varieties revealed values for these parameters quite different, from weak to very strong flour, but are closer to the average flour classification.

FariRamos flour showed the significantly highest value (99.4 mm) for toughness (P), with Nacional flour having the lowest one $(82.1 \mathrm{~mm}$ ) (Table 5). Regarding extensibility (L), a decreasing value prevailed (Table 5 ) in the sequence AJMiranda ( $86.9 \mathrm{~mm})$, Nacional $(70.8 \mathrm{~mm})$ and FariRamos $(64.7 \mathrm{~mm})$. P/L ratio revealed a higher value for FariRamos flour (1.5), followed by the Nacional flour (1.2) and AJMiranda flour (1.0). Regarding the overall gluten strength (W), AJMiranda presented a higher value (242.0 xJ), as opposed to the Nacional $205.4 \times \mathrm{J}$ ) which revealed the lowest value. There must be a balance between $\mathrm{L}$ and P. The higher the $\mathrm{L}$ value, the greater the bread volume, although dependent on the $\mathrm{P}$ value. This balance reflects the $\mathrm{P} / \mathrm{L}$ ratio associated with the value of $\mathrm{W}$. Values of $\mathrm{P} / \mathrm{L}$ below 0.60 can be considered as extensible gluten, from 0.61 to 1.20 balanced gluten, and values above 1.21 tenacious gluten (Guarienti, 1996). For the analysed flours, FariRamos flour presented a tenacious gluten and the remaining flours a balanced gluten. Also, according to the value of $\mathrm{W}$, various intensities for gluten strength can be considered, from very weak to very strong. A very weak gluten flour has a W value of $\leq 50 \times \mathrm{J}$. A weak gluten flour has a W value of 51-100 x J. A medium gluten flour has a W value between 101-200 xJ. A medium-strong gluten flour

Table 5:Alveographic test of wheat flours ( $P=$ Tenacity; $\mathrm{L}=$ Extensibility; $\mathrm{P} / \mathrm{L}=$ Equilibrium ratio; $\mathrm{W}=$ Force)

\begin{tabular}{lcccc}
\hline Flours & $\mathbf{P}(\mathbf{m m})$ & $\mathbf{L}(\mathbf{m m})$ & $\mathbf{P} / \mathbf{L}$ & W $(\mathrm{E}-4 \mathrm{~J})$ \\
\hline FariRamos & $99.4 \pm 2.2^{\mathrm{a}}$ & $64.7 \pm 4.0^{\mathrm{b}}$ & $1.5 \pm 0.1^{\mathrm{a}}$ & $232 \pm 7.9^{\mathrm{a}}$ \\
AJMiranda & $83.9 \pm 1.4^{\mathrm{b}}$ & $86.9 \pm 3.3^{\mathrm{a}}$ & $1.0 \pm 0.1^{\mathrm{a}}$ & $242.6 \pm 3.8^{\mathrm{a}}$ \\
Nacional & $82.1 \pm 2.3^{\mathrm{b}}$ & $70.8 \pm 10.5^{\mathrm{a}, \mathrm{b}}$ & $1.2 \pm 0.2^{\mathrm{a}}$ & $205.4 \pm 20.6^{\mathrm{a}}$
\end{tabular}

Each value is the mean \pm S.E. of three samples of each flour. Letters a,bindicate significant differences, of each parameter, among wheat flours (statistical analysis using the one-way analysis of variance, $P \leq 0.05$ ) has a W-value ranging from 201-300 xJ. A strong flour has a W-value ranging from 301-400 x J. Finally a very strong flour has values of $\mathbb{W} \geq 401 \times J$ (Guarienti, 1996). For the analysed flours, for the $\mathrm{W}$ parameter, the 3 varieties fall into the medium-strong gluten flours.

Bread produced with FariRamos, AJMiranda and Nacional flours and sprayed with acetic acid, benzoic acid and methyl p-hydroxybenzoate revealed some differences among the colorimetric parameters (Table 6). Parameter L, in the interior of the different breads sprayed with methyl p-hydroxybenzoate showed higher values, indicating a lighter crumb, whereas in the samples with benzoic acid, and in the bread without additives, similar values prevailed and in bread with acetic acid lower values were detected, therefore indicating a darker colour. Significant differences were not found in the kernel for this parameter. In the upper crust this parameter showed higher values, with acetic acid having the highest values, followed by methyl p-hydroxybenzoate, and finally benzoic acid and bread without additives displaying the lowest values. The bread without additives, with benzoic acid [0.1\%] and with methyl p-hydroxybenzoate, in the two concentrations did not show significant differences in relation to the others. Bread with benzoic acid [0.05\%] showed significant differences compared to bread with acetic acid, however between both concentrations of acetic acid there were no significant differences. Still on the lower end of the crust, bread with the benzoic acid showed the highest values, followed by bread without additives and with bread with methyl p-hydroxybenzoate and acetic acid displaying the lowest values. No significant differences were also detected.

Regarding parameter $a^{*}$ inside the bread, spray with acetic acid showed higher values, followed by bread containing benzoic acid and lastly the bread with methyl -phydroxybenzoate and without additives. The bread without additives, with benzoic acid in both concentrations, and methyl p-hydroxybenzoate [0.05\%] or acetic acid [4\%] showed no significant differences among themselves, nor between the other breads. Bread with methyl p-hydroxybenzoate $[0.03 \%]$ showed significant differences compared to bread with acetic acid [3\%]. Contrary to what was observed for the inner part of the breads, in the upper part of the crust the quantified values were more dispersed among additives and their concentrations. That is, the highest value was found after spraying with benzoic acid $[0.05 \%]$, followed by bread without additives then with methyl p-hydroxybenzoate $[0.05 \%]$, followed by benzoic acid $[0.1 \%]$ and finally the lowest values corresponding to acetic acid for both concentrations used. In bread without additives, with benzoic acid in both concentrations and with methyl p-hydroxybenzoate $[0.05 \%]$ no significant differences were found. These, in relation to methyl 
Table 6: Colorimetric parameters of the bread produced with FariRamos, AJMiranda and Nacional flours and sprayed with the following food additives: benzoic acid (B.A., concentrations $0.05 \%$ and $0.1 \%$ ), methyl p-hydroxybenzoate (H.B., concentrations $0.03 \%$ and $0.05 \%$ ) and acetic acid (A.A., concentrations $3 \%$ and $4 \%$ )

\begin{tabular}{|c|c|c|c|c|}
\hline \multirow[t]{2}{*}{ Additives } & \multirow[t]{2}{*}{ Analysis location in the bread } & \multicolumn{3}{|c|}{ Colour parameters } \\
\hline & & L & $a^{*}$ & $\mathbf{b}^{*}$ \\
\hline \multirow[t]{3}{*}{ None } & Crumb & $52.65 \pm 3.65^{a}$ & $0.94 \pm 0.13^{\mathrm{ab}}$ & $19.98 \pm 0.82^{a}$ \\
\hline & Top cover & $60.92 \pm 4.77^{\mathrm{ab}}$ & $8.59 \pm 1.09^{a}$ & $28.26 \pm 0.92^{a}$ \\
\hline & Bottom cover & $56.70 \pm 6.61^{\mathrm{a}}$ & $7.74 \pm 1.86^{b}$ & $20.81 \pm 1.90^{a}$ \\
\hline \multirow[t]{3}{*}{ B.A. $[0.05 \%]$} & Crumb & $52.7 \pm 0.60^{\mathrm{a}}$ & $1.44 \pm 0.61^{\mathrm{ab}}$ & $20.61 \pm 1.08^{a}$ \\
\hline & Top cover & $56.23 \pm 3.29^{b}$ & $9.18 \pm 0.30^{\mathrm{a}}$ & $28.39 \pm 0.19^{a}$ \\
\hline & Bottom cover & $59.2 \pm 6.61^{\mathrm{a}}$ & $7.28 \pm 1.89^{b}$ & $22.37 \pm 1.96^{a}$ \\
\hline \multirow[t]{3}{*}{ B.A. [0.1\%] } & Crumb & $52.28 \pm 5.65^{\mathrm{a}}$ & $1.36 \pm 0.40^{\mathrm{ab}}$ & $20.02 \pm 0.07^{a}$ \\
\hline & Top cover & $64.66 \pm 2.02^{\mathrm{ab}}$ & $6.80 \pm 0.48^{a}$ & $24.41 \pm 2.34^{a}$ \\
\hline & Bottom cover & $55.99 \pm 2.57^{\mathrm{a}}$ & $10.29 \pm 0.09^{a b}$ & $26.26 \pm 0.06^{a}$ \\
\hline \multirow[t]{3}{*}{ H.B [0.03\%] } & Crumb & $55.77 \pm 0.36^{a}$ & $0.59 \pm 0.09^{b}$ & $19.18 \pm 0.13^{a}$ \\
\hline & Top cover & $65.8 \pm 1.33^{\mathrm{ab}}$ & $6.34 \pm 0.35^{\mathrm{ab}}$ & $23.92 \pm 1.75^{\mathrm{ab}}$ \\
\hline & Bottom cover & $54.94 \pm 3.09^{\mathrm{a}}$ & $9.88 \pm 0.63^{\mathrm{ab}}$ & $25.72 \pm 0.16^{a}$ \\
\hline \multirow[t]{3}{*}{ H.B [0.05\%] } & Crumb & $53.81 \pm 3.10^{\mathrm{a}}$ & $0.96 \pm 0.22^{\mathrm{ab}}$ & $20.45 \pm 1.06^{a}$ \\
\hline & Top cover & $64.92 \pm 0.30^{\mathrm{ab}}$ & $7.56 \pm 0.27^{a}$ & $27.35 \pm 0.07^{a}$ \\
\hline & Bottom cover & $50.08 \pm 1.92^{\mathrm{a}}$ & $10.81 \pm 1.63^{\mathrm{ab}}$ & $26.08 \pm 1.35^{a}$ \\
\hline \multirow[t]{3}{*}{ A.A [3\%] } & Crumb & $46.78 \pm 2.52^{\mathrm{a}}$ & $1.81 \pm 0.05^{\mathrm{a}}$ & $19.26 \pm 0.02^{a}$ \\
\hline & Top cover & $71.61 \pm 5.37^{a}$ & $3.74 \pm 1.20^{\mathrm{bc}}$ & $19.06 \pm 0.18 c$ \\
\hline & Bottom cover & $46.8 \pm 2.01^{a}$ & $13.28 \pm 0.47^{a}$ & $27.21 \pm 1.43^{a}$ \\
\hline \multirow[t]{3}{*}{ A.A [4\%] } & Crumb & $50.69 \pm 7.52^{\mathrm{a}}$ & $1.65 \pm 0.02^{\mathrm{ab}}$ & $19.89 \pm 0.01^{a}$ \\
\hline & Top cover & $71.7 \pm 0.08^{a}$ & $2.77 \pm 0.79 c$ & $19.56 \pm 1.30^{\mathrm{bc}}$ \\
\hline & Bottom cover & $49.66 \pm 3.25^{a}$ & $12.73 \pm 0.53^{a}$ & $27.12 \pm 3.71^{\mathrm{a}}$ \\
\hline
\end{tabular}

Each value is the mean \pm S.E. of three samples of each flour; Letters ${ }^{a, b, c i n d i c a t e ~ s i g n i f i c a n t ~ d i f f e r e n c e s, ~ o f ~ e a c h ~ p a r a m e t e r ~(c r u m b, ~ t o p ~ o r ~ b o t t o m ~ c o v e r s ~ o f ~ t h e ~}$ bread), among the different bread samples treated or not with the food additives (statistical analysis using the one-way analysis of variance, $\mathrm{P} \leq 0.05$ )

p-hydroxybenzoate [0.03\%], also showed no significant differences, but in relation to bread with acetic acid in the two concentrations significant differences were found. Bread with methyl p-hydroxybenzoate $[0.03 \%]$ and with acetic acid [3\%] showed significant differences. Considering both concentrations of acetic acid sprayed in the bread, no significant differences were detected. As for the bottom of the crust the same trend was observed, with the values being dispersed. Bread with acetic acid showed the highest values at both concentrations, followed by bread with methyl p-hydroxybenzoate [0.05\%], then with benzoic acid [0.1\%], and methyl p-hydroxybenzoate [0.03\%], and finally bread without additives and with benzoic acid [0. 05\%]. Breads with acetic acid showed no significant differences between them, neither in relation to bread with benzoic acid [0.1\%], nor in relation to bread with methyl p-hydroxybenzoate in both concentrations, but showed significant differences in relation to bread with benzoic acid [0.05\%] and bread without additives. Bread with benzoic acid [0.1\%] and with methyl p-hydroxybenzoate, in both concentrations, did not present significant differences among themselves, nor in relation to the other breads. Bread without additives and bread with benzoic acid [0.05\%] showed no significant differences between them.

For parameter $\mathrm{b}^{*}$, it was found that inside the bread the values were dispersed between the samples with additives and the respective concentrations, with the highest values

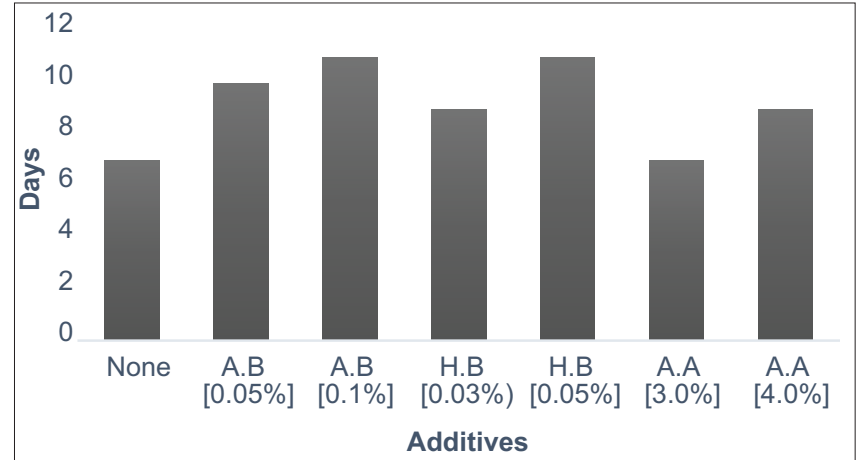

Fig 1. Shelf-life of the bread produced with FariRamos, AJMiranda and Nacional flours and sprayed with the following food additives: benzoic acid (B.A., concentrations $0.05 \%$ and $0.1 \%$ ), methyl p-hydroxybenzoate (H.B., concentrations $0.03 \%$ and $0.05 \%$ ) and acetic acid (A.A., concentrations $3 \%$ and $4 \%$ ).

in decreasing order corresponding to: bread with benzoic acid $[0,05 \%]$, methyl p-hydroxybenzoate $[0.05 \%]$, benzoic acid [0.1\%], bread without additives, with acetic acid in both concentrations and with methyl p-hydroxybenzoate $[0.03 \%]$. No significant differences were detected among bread samples. The top crust of the bread showed the highest value with benzoic acid [0.05\%], followed by bread without additives, with methyl p-hydroxybenzoate [0.05\%], with benzoic $[0.1 \%]$, with methyl p-hydroxybenzoate $[0.03 \%]$ and with acetic acid in both concentrations. Bread without additives, with benzoic acid in both concentrations and with methyl p-hydroxybenzoate $[0.05 \%]$ did not show 


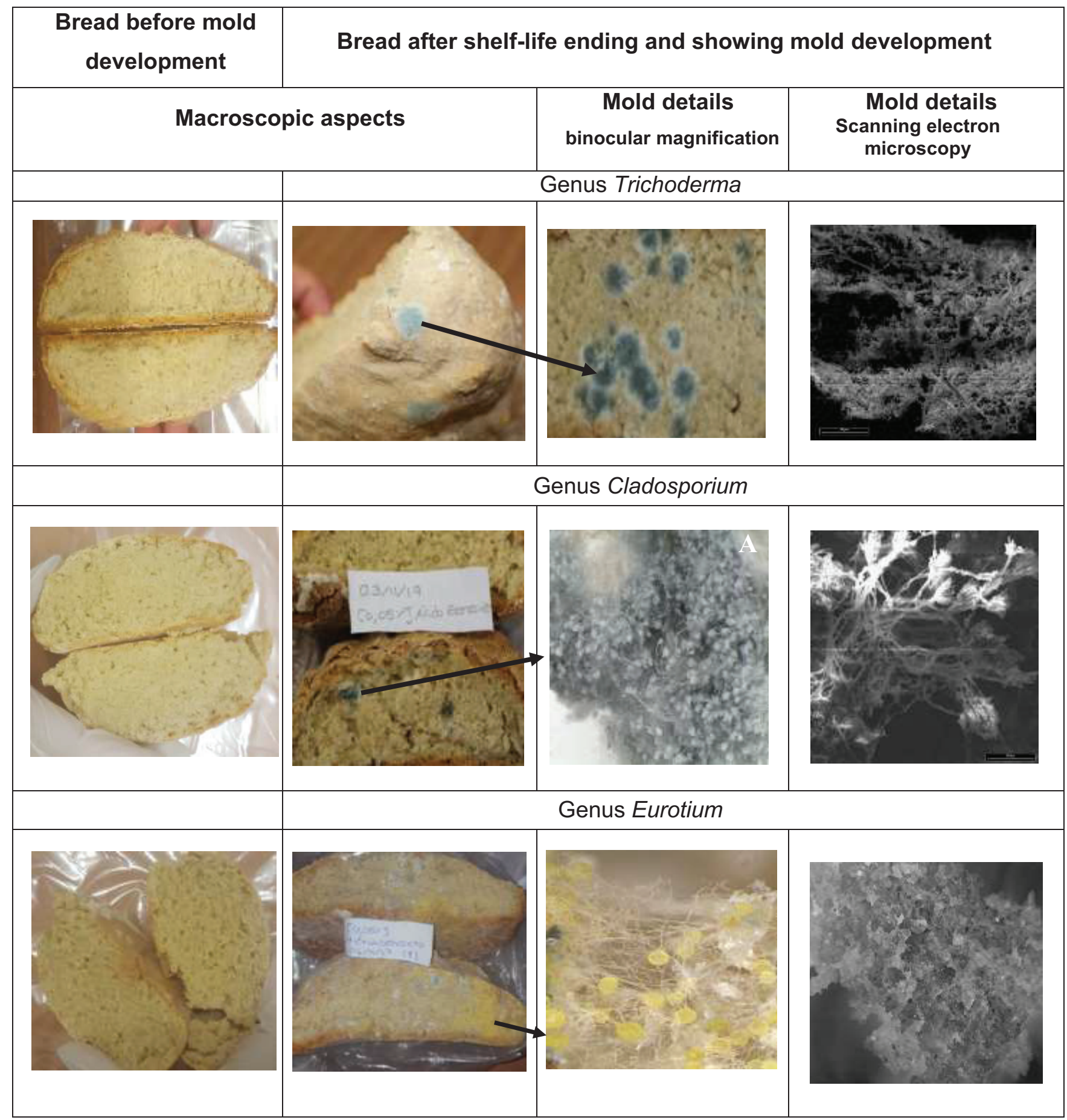

Fig 2. Macroscopic and microscopic aspects showing mold development after shelf-life ending of the bread produced with FariRamos, AJMiranda and Nacional flours and sprayed with food additives.

significant differences among themselves, nor with bread with methyl p-hydroxybenzoate [0.03\%], but there were significant differences with breads with acetic acid. The latter showed no significant differences among themselves, but revealed significant differences in relation to the others. Relatively to the bottom of the bread crust, the highest value was for bread containing acetic acid at both concentrations, followed by bread with acetic acid [0.1\%], with methyl p-hydroxybenzoate at both concentrations, with benzoic acid $[0.05 \%]$ and bread without additive. No significant differences were detected between the different bread samples.

Incorporation of food additives to increase the bread's shelf life showed (Fig. 1) that benzoic acid [0.1\%] and methyl p-hydroxybenzoate $[0.05 \%]$ had a higher efficiency, 
reaching 11 days. Methyl p-hydroxybenzoate with a lower concentration was as effective as benzoic acid. Bread with methyl p-hydroxyzenzoate $[0.03 \%]$ and benzoic acid $[0.05 \%]$ maintained quality for 9 and 10 days respectively. Bread with acetic acid at 3\% concentration had a shelflife of 7 days and, at 4\%, 9 days. Thus, this additive compared to others was not as effective and had a strong smell. Regardless of the incorporation of these food additives, after shelf-life ending, they developed without an apparent sequence, yellow, green and black molds (Fig. 2), corresponding to the genera Eurotium, Trichoderma and Cladosporium, respectively (Freitas and Figueiredo, 2000; Almeida et al., 2010).

\section{CONCLUSION}

The concept of wheat flour quality is closely related to its industrial destiny. Thus, the quality parameters vary according to the different types of wheat, whose flours have different industrial use - bakery, cake and cookie flours and other confectionery and pasta products. In this context, it was found that the quality of FariRamos, AJMianda and Nacional flours cannot be defined considering a single property or parameter. However, there are minimum quality indexes that will set limits below which wheat flour may be considered unfit for use in baking or in the mass and pasta industry. This was not the case for the flour varieties studied, as the levels of mineral elements, protein, fatty acids, and gluten fall within ranges considered optimal for baking. At the technological level, they can also be attributed to the classification of medium flour with tenacious gluten (FariRamos) or balanced gluten (AJMiranda and Nacional). Besides, considering the W parameter, all flours have a medium-strong gluten. Equating the bread shelf-life produced with these flours it was found that the most effective additives were methyl p-hydroxybenzoate $[0.05 \%]$ and benzoic acid [0.1\%]. It was also verified, regarding the colorimetric parameters, that with parameter $\mathrm{L}^{*}$ it was possible to establish a pattern of the additives that give a whiter colour, but in relation to the other parameters the values are dispersed between the different additives and the different concentrations, making it difficult to establish a pattern. Following a general perspective, it was verified that these chemical and technological indexes can be used for a structured and integrated characterization of the different varieties of flour, making possible to direct their use in the baking industry and to establish minimum commercialization prices.

\section{Funding}

This work support from national funds from Fundação para a Ciência e a Tecnologia (FCT), Portugal, through the research units UID/GEO/04035/2019 (GeoBioTec) and UID/AGR/04129/2019 (LEAF).

\section{Author Contributions}

All authors contributed equally to the production of the manuscript.

\section{REFERENCES}

Almeida, I., E. Costa and R. Guine. 2010. Caracterização Bioquímica e Fúngica de Peras Secadas por Diferentes Processos. Livro de Resumos e CD-Rom das Actas do $1^{\circ}$ Encontro Português de Secagem de Alimentos. Viseu, Portugal.

Araújo, W. M. A. 1990. Efeito da Adição Farinha de Soja Desengordurada Como Fonte de Lipoxigenase Ativa de Soja nas Características Reológicas e na Distribuição dos Lípidos na Massa de Farinha de Trigo. UNICAMP, Campinas, Brasil.

Bagulho, A. S. 2008. Efeito das Proteínas de Reserva e das Associadas ao Amido e Aos Lípidos nas Propriedades Reológicas da Farinha de Trigo Mole. Universidade Técnica de Lisboa, (Doctoral Thesis) Instituto Superior de Agronomia, Lisbon, Portugal.

Bahrami, B., L. Yonekura, R. Linforth, M. C. Silva, S. Hill, S. Penson and G. Chope. 2014. Comparison of ambient solvent extraction methods for the analysis of fatty-acids in non-starch lipids of wheat and barley flour and maize and tapioca starch. J. Sci. Food Agric. 94: 415-423.

Becker, R. 2007. In: Fatty Acids in Foods and their Health Implications. $3^{\text {rd }}$ ed. CRC Press, Boca Raton, Florida.

Bligh, E. G. and W. J. Dyer. 1959. A rapid method for total lipid extraction and purification. Can. J. Biochem. Physiol. 3: 991-917.

Dias, A. S., F. C. Lidon and J. C. Ramalho. 2009a. I. Heat stress in Triticum: Kinetics of $\mathrm{Ca}$ and $\mathrm{Mg}$ accumulation. Braz. J. Plant Physiol. 21: 123-134.

Dias, A. S., F. C. Lidon and J. C. Ramalho. 2009b. III. Heat stress in Triticum: Kinetics of $\mathrm{Na}, \mathrm{K}$ and $\mathrm{P}$ accumulation. Braz. J. Plant Physiol. 21: 143-152.

Dick, J. and W. J. S. Quick. 1983. A modified screening test for rapid estimation of gluten strength in early-generation durum wheat breeding lines. J. Cereal Chem. 60: 315-318.

Dick, J. W. and R. R. Matsuo. 1988. Durum wheat and pasta products. In: Wheat: Chemistry and Technology. Vol. 2. American Association of Cereal Chemists, St. Paul, Minnesota, pp. 507-547.

Din, A., I. Pasha, F. M. Anjum, M. R. Khan, M. Saeed and M. U. Arshad. 2007. Wheat gluten: high molecular weight glutenin subunits structure, genetics, and relation to dough elasticity. J. Food Sci. 72: 56-63.

Edwards, N. M., D. Peressini, J. E. Dexter and S. J. Mulvaney. 2001. Viscoelastic properties of durum wheat and common wheat dough of different strengths. Rheol. Acta 40: 142-153.

El-Dash, A. C. O. Ahmed, N. Camargo and M. Diaz. 1990. Composição química do grão de trigo e da farinha In: Fundamentos da Tecnologia de Panificação. Secretaria da Industria, Comércio, Ciência e Tecnologia Eds, São Paulo, Brasil.

Elias, E. M. 1995. Durum wheat products. In: N. Di Fonzo, F. Kaan and M. Nachit M (Eds.), Durum Wheat Quality in the Mediterranean Region. Vol. 22. Options Méditerranéennes: Série A. Séminaires Méditerranéens, pp. 23-31.

Freitas, A. C. and P. Figueiredo. 2000. Conservação de Alimentos. Available from: http://www.users/fj//downloads/freitas-\%20 figueiredo- $\% 202000 \% 20-\% 20$ conservacao $\% 20$ dos $\% 20$ alimentos\%20-\%20livro.pdf. [Last accessed on 2019 Jul].

Fukunaga, K. 1970. Methods of quality tests in wheat breeding. Jpn. 
Agric. Res. Q. 5: 15-20.

Groover, K. D. and J. A. Izbicki. 2016. Elemental analysis using a handheld X-ray fluorescence spectrometer. U.S. Geological Survey Fact Sheet, No. 2015-3043, USA.

Guarienti, E. M. 1996. In:. ,Qualidade Industrial do Trigo. $2^{\text {nd }}$ ed. EMBRAPA-CNPT, Passo Fundo, Brasil.

ISO 20483-E. 2006. Cereals and Pulses Determination of the Nitrogen Content and Calculation of the Crude Protein Content Kjeldahl Method. International Standardization Organization, Geneva, Switzerland.

ISO 21415-2:2006. 2006. Wheat and Wheat Flour Content Part 2: Determination of Wet Gluten by Mechanical Means. $1^{\text {st }}$ International Standardization Organization. Switzerland, Geneva.

ISO 21415-4:2006. 2006. Wheat and Wheat Flour Gluten Content Part 4: Determination of Dry Gluten from Wet Gluten by a Rapid Drying Method. $1^{\text {st }}$ ed. International Standardization Organization. Geneva, Switzerland.

ISO 3093:2009. 2009. Wheat, Rye and their Flours, Durum Wheat and Durum Wheat Semolina Determination of the falling Number According to Hagberg Perten. $4^{\text {th }}$ ed. International Standardization Organization. Geneva, Switzerland.

ISO 5530-1:2013. 2013. Wheat Flour Physical Characteristics of Doughs Part 1: Determination of Water Absorption and Rheological Properties Using a Farinograph. $3^{\text {rd }}$ International Standardization Organization. Geneva, Switzerland.

ISO/DIS 27971:2014-E. 2014. Cereals and Cereal Products Common Wheat (Triticum aestivum L.) Determination 50 of Alveograph Properties of dough at Constant Hydration from Commercial or Test Flours and Test Milling Methodology. $1^{\text {st }}$ ed. International Standardization Organization, Geneva, Switzerland.

Mandarino, J. M. G. 1993. Aspectos Importantes Para a Qualidade do Trigo. Embrapa-CNPO, Brasil, Londrina.

Quitmann, H., R. Fan and P. Czermak. 2014. Acidic organic compounds in beverage, food, and feed production. Adv. Biochem. Eng. Biotechnol. 143: 91-141.

Lidon, F. C. and M. M. A. Silvestre. 2007. Indústrias Alimentares Aditivos e Tecnologias. Escolar Editora, Lisboa, Portugal.

Lidon, F. C. and M. M. A. Silvestre. 2008. Conservação de Alimentos Princípios e Metodologias. Escolar Editora, Lisboa, Portugal.

Lidon, F. C. and M. M. A. Silvestre. 2010. Princípios de Nutrição e Alimentação Humana. Escolar Editora, Lisboa, Portugal.

Lucas, I., H. Petermeier, T. Becker and M. Jekle. 2019. Definition of network types prediction of dough mechanical behaviour under shear by gluten microstructure. Sci. Rep. 9: 4700.

Mazliak, P. 1983. Plant membrane lipids: Changes and alterations during aging and senescence. In: M. Lieberman (Ed.), PostHarvest Physiology and Crop Preservation. Nato Advanced Study Institutes Series (Series A: Life Sciences). Vol. 46. Springer, Boston, MA.

Monho, A. T. 2013. Determinação do Valor Tecnológico e de Utilização de Vários Tipos de Misturas de Farinha de Trigo Mole e Sêmola de Trigo Duro Para o Fabrico de pão Tradicional. (Master Thesis) Faculdade de Ciências e Tecnologia, Universidade Nova de Lisboa, Lisboa, Portugal.

NP 516/2000. 2000. Cereais e Derivados. Determinação do Teor de Água. Método Prático de Referência. Instituto Português da Qualidade, Portugal.

NP 519/1993. 1993. Cereais e Derivados. Determinação do Teor de Cinza a $900^{\circ} \mathrm{C}$. Processo Corrente. Instituto Português da Qualidade, Portugal.

Oliveira, K. 2012. Stresse Térmico em Plantas de Trigo. Alterações na Composição do Grão. (Master Thesis) Faculdade de Ciências e Tecnologia da Universidade Nova de Lisboa, Portugal.

Ortolan, F. 2006. Genótipos de Trigo do Paraná Safra 2004: Caracterização e Fatores Relacionados à Alteração de cor de Farinha. Universidade Federal de Santa Maria, Santa Maria, Brasil.

Peterson, C. J., V. A. Johnson and P. J. Mattern. 1983. Evaluation of variation in mineral element concentrations in wheat flour and bran of different cultivars. Cereal Chem. 60: 450-455.

Posner, E. S. and A. N. Hibbs. 2005. Wheat Flour Milling. American Association of Cereal Chemists (Eds.) Inc., St. Paul, Minnesota, USA.

Remelgado, T. L. T. 2016. Qualidade e segurança alimentar no fabrico de farinhas de trigo. Relatório de Estágio Profissionalizante, Escola Superior Agrária. Coimbra, Portugal.

Rennan, G. O., S. M. M. Araújo, M. G. A. Korn, M. F. Pimentel, R. E. Brun and S. L. C. Ferreira. 2008. Mineral Composition of Wheat Flour Consumed in Brazilian Cities. J. Braz. Chem. Soc. 19: 936-942.

Rocha, A. F. 2009. Cádmio, Chumbo, Mercúrio a Problemática Destes Metais Pesados na Saúde Pública? Faculdade de Ciências da Nutrição e Alimentação, Universidade do Porto, Porto, Portugal.

Scheuer, P. M., A. Francisco, M. Z. Miranda and V. M. Limberger. 2011. Trigo: Características e utilização na panificação. Rev. Bras. Prod. Agroind. 13: 211-222.

Sgarbieri, V. C. 1987. Alimentação e Nutrição Fator de Saúde e Desenvolvimento. UNICAMP, São Paulo, Almed, Brasil.

Silva, R. C. 2003. Qualidade Tecnológica e Estabilidade Oxidativa de Farinha de Trigo e Fubá Irradiados. (Master Thesis) Universidade de São Paulo, Brasil.

Silva, R. C., L. M. Pino, M. H. F. Spoto and M. A. B. D'Arce. 2010. Oxidative and sensorial stability of radiated wheat and corn flour. Food Sci. Technol. 30: 406-413.

Silva, M. M. and F. C. Lidon. 2016. Food preservatives an overview on applications and side effects. Emir. J. Food Agric. 28: 366-373.

Stanley, P. C. 2007. Wheat and Flour Testing Methods: A Guide to Understanding Wheat and Flour Quality. Wheat Marketing Center, Inc., Portland, Oregon USA.

Zardo, F. P. 2010. Analises Laboratoriais Para o Controle de Qualidade da Farinha de Trigo, Instituto Federal de Ciência e Tecnologia do Rio Grande do Sul, Campus Bento Gonçalves, Brasil. 